\title{
Diacylglycerol Kinase Eta
}

National Cancer Institute

\section{Source}

National Cancer Institute. Diacylglycerol Kinase Eta. NCI Thesaurus. Code C119660.

Diacylglycerol kinase eta (1220 aa, 135 kDa) is encoded by the human DGKH gene. This protein plays a role in the phosphorylation of diacylglycerol. 